\title{
THE TECHNOLOGY GAP
}

A GREAT deal of well-intentioned nonsense is to be heard about the phenomenon called the technology gap, and there is a danger that it is infectious. The assertion is that Europe lags behind the United States in technological prowess, that the gap is steadily increasing, and that some means should be found for making it melt away. The Italian Government first raised the banners of deprivation early in the autumn of 1966. Mr. Harold Wilson, the British Prime Minister, echoed with a vision of how Britain could contribute more than most nations to the creation of a technological community in Western Europe. Towards the end of the year, both the President of the United States and the secretariat of the OECD embarked on special studies, and just before Christmas the issue came up in the Council of the North Atlantic Treaty Organization. Evidently the months ahead will be fully occupied with committee meetings of all kinds. Unhappily there is nothing like the same assurance that there will be agreement on whether there is a phenomenon which can be described as a technology gap, whether if it exists it is to be deplored or counted a blessing, and how, if at all, it might be removed or at least diminished.

The first need is to know what problem should be tackled. Although there is no reason to think that Europe is intrinsically incapable of some of the technological feats now being carried out in the United States, the plain fact is that advanced technology is much less obvious in Europe. But there is a similar disparity between Europe and North America in the general level of industrial production, in personal incomes (which determine the sizes of markets for goods of all kinds), and even in the amounts of food consumed. And if Europe sometimes looks a little woebegone in comparison with the United States, it nevertheless seems unattainably sophisticated in comparison with the developing nations and those which are hardly developing at all.

In all these comparisons, the problem is to decide which comes first-the prosperity or the technology. By now there is plenty of evidence that technological developments alone do not bring prosperity. The collaboration of European nations in the development of the European space launcher under the umbrella of ELDO is unlikely to add much to the industrial competitiveness of the member countries. Certainly there would have been a better return from the invest. ment of $£ 100$ million or so in more pedestrian development work-computers or even diesel engines, for example. Equally, the decision to commit $£ 500$ million to the Anglo-French development of a supersonic aircraft is unlikely to yield that amount of benefit to the economies of the countries concerned. And even in the United States, it may well turn out that the Apollo programme to put a man on the Moon will prove to be more a drag on the economy than an incentive. What is called spin-off is grossly overvalued. The moral in all these cautionary tales is that lasting technological success depends on the existence of a healthy demand for its products. From this point of view, it is encouraging that the British Government seems to conceive of its European technological community in the context of the Common Market.

What, then, is likely to be done in Europe ? Much more should be known about the British contribution after the Prime Minister and the Foreign Secretary have trudged around the capitals of the members of the European Economic Community in the next few weeks. No doubt they will make as much as they can of the contribution that British technology could make to the pace of development in Europe as a whole, and that will be entirely proper. But even if their enquiries result in a cheerful forecast about British and Scandinavian membership of the European Community, there will be a great deal of solid drudgery ahead. Working out common procedures for industrial specifications, testing procedures and patent applications will be a necessary preliminary - and progress on these matters within the Common Market has not been nearly as rapid as was at first expected. It would not be surprising if the amendment of national company legislation turned out to be high on the list of humdrum needs, together with arrangements for helping skilled people to move more easily from one place to another. At this stage, there is much less scope for the more ambitious schemes which are sometimes talked about-although there is a great deal which could be done immediately to put public laboratories more freely at the disposal of Europe as a whole. But none of these devices, and the more ambitious schemes which might follow, will work if the economic climate is not right. Mercifully, nobody seems to think that Europe can be turned into an engineers' Aladdin's Cave by investing money and effort in spectacular technology.

\section{ONE BASKET FOR EGGS}

Wirt the possible exception of a few men in Seattle, nobody will cry chicken because President Johnson and the United States Government have not followed the choice of the Boeing Aircraft Company as super- 